\title{
Report of the complex geoarcheological survey at the Ecse-halom kurgan in Hortobágy, Hungary
}

\author{
Ádám Bede ${ }^{1 *}$, Roderick B. Salisbury ${ }^{2}$, András István Csathó ${ }^{3}$, Péter Czukor ${ }^{1}$, \\ Dávid Gergely Páll ${ }^{4}$, Gábor Szilágyi ${ }^{5}$, Pál Sümegi ${ }^{4}$
}

\author{
${ }^{1}$ Móra Ferenc Museum, Szeged, Hungary \\ ${ }^{2}$ Vienna Institute for Archaeological Science, Vienna, Austria \\ ${ }^{3}$ Institute of Ecology and Botany, MTA Centre for Ecological Research, Vácrátót, Hungary \\ ${ }^{4}$ Department of Geology and Paleontology, University of Szeged, Szeged, Hungary \\ ${ }^{5}$ Hortobágy National Park Directorate, Debrecen, Hungary
}

Received: January 19, 2015; accepted: June 1, 2015

The Ecse-halom is a burial mound (kurgan) in the Hortobágy region of Hungary. Built in the Late Copper Age/Early Bronze Age by nomadic people from the east, it now stands on the border between two modern settlements. A road of medieval origin runs along this border and cuts deeply into the body of the mound. The southern half of the mound was plowed and used as a rice field, and later a military observation tower was built on top of it. Despite this disturbance, the surface of the mound is in decent condition and provides a home for regionally significant, species-rich loess steppe vegetation. The mound comprises two construction layers as indicated by magnetic susceptibility and thin-section micro-morphological analysis. Examination of organic compounds and carbonate content at various levels showed different values, which suggest a variety of natural and anthropogenic stratigraphic layers. Mid-sized siltstone fraction is dominant in the section. The layers originate from the immediate vicinity of the mound, but have different characteristics than present-day soils. These mounds contain a valuable record of cultural and environmental conditions occurring at the time of their construction, and also serve as a refuge for ancient loess vegetation; therefore their conservation is highly recommended.

Keywords: Great Hungarian Plain, kurgan, geoarcheology, sedimentology, micro-morphology

*Corresponding author: Roosevelt tér 1-3, H-6720 Szeged, Hungary;

E-mail: bedeadam@gmail.com 


\section{Introduction}

Only a few ancient architectural monuments remain standing in the central region of the Great Hungarian Plain. Tartars, Turks and other invaders destroyed numerous important buildings and structures that could not be rebuilt. However, some unique 5000-year-old treasures still exist in this area. These are the kurgans (Ecsedy 1979; Anthony 2007), the mound-graves of the Yamnaya culture. The Yamnaya were nomadic people who built large burial mounds during the Late Copper and Early Bronze Age. Eastern Hungary is the westernmost extent of the Yamnaya culture, which is best known from the steppe zone of Eurasia. Their burial mounds can be found along the banks of defunct rivers and at some points of higher elevation on the plain (Ecsedy 1979; Horváth 2011; Dani and Horváth 2012).

These mounds are very important from archeological, paleoecological and cultural heritage perspectives, and are a salient cultural element of the landscape. Through detailed and complex study they provide information not only on the life history, archeological heritage and customs of the people buried inside them, but also on the environment, the ancient flora and fauna, and the geologic formations that existed at the time of their construction (Barczi et al. 2011; Pető and Barczi 2011; Sudnik-Wójcikowska et al. 2011; Szilágyi et al. 2013). Data from these sites can be augmented and contrasted with that from other archeological environmental studies from the Hungarian Plain (e.g. Sümegi et al. 2005; Molnár and Sümegi 2007; Salisbury et al. 2013). In the 18th century the number of kurgans on the Great Hungarian Plain was estimated to be around 25,000, but many of these vanished in the past two centuries due to infrastructure development and agricultural practices. Only a few hundred remain in good condition (Tóth 1988), and many of these suffer the effects of plowing and erosion. Hungary has laws to protect kurgans and other cultural monuments, but lacks the resolution and capability for practical enforcement.

In order to help documenting and preserving the remaining mounds and the data they contain, it is necessary to perform thorough archeological, environmental historical, topographical and morphological surveys of these monuments. This work requires intensive field studies in conjunction with examination of archives and maps. The Ecse-halom kurgan (mound) in the Hortobágy National Park is a good candidate for such research because it has been badly damaged in the past and remains at risk of complete destruction.

In this paper, we present the preliminary results of this research, including geomorphologic, landscape historical, botanical, sedimentological and micro-morphological results.

\section{Hortobágy and the Ecse-halom kurgan}

In 2012, a research project was launched to investigate the Ecse-halom (Sümegi 2012). The Hortobágy National Park is part of the Hortobágy plain, a region within the Great Hungarian Plain. Historically part of the Nagykunság (Greater Cumania), 
the Hortobágy plain is a flat, low-lying steppe-land of highly alkaline soils that are more suited to pasture than agriculture. The substratum is redeposited loess that was fluvially reworked during the Pleistocene. Vegetation today is dominated by non-ar-

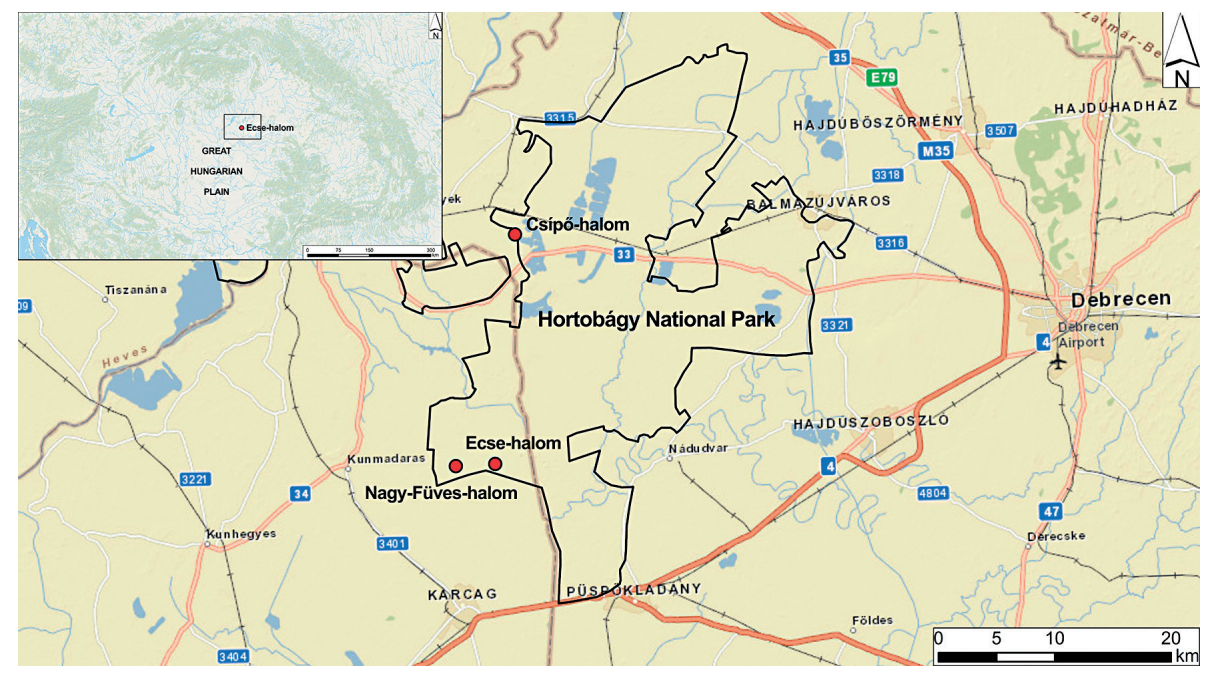

Fig. 1

The Ecse-halom in the Great Hungarian Plain with the Hortobágy National Park, between Karcag and Kunmadaras (map by ArcGIS)

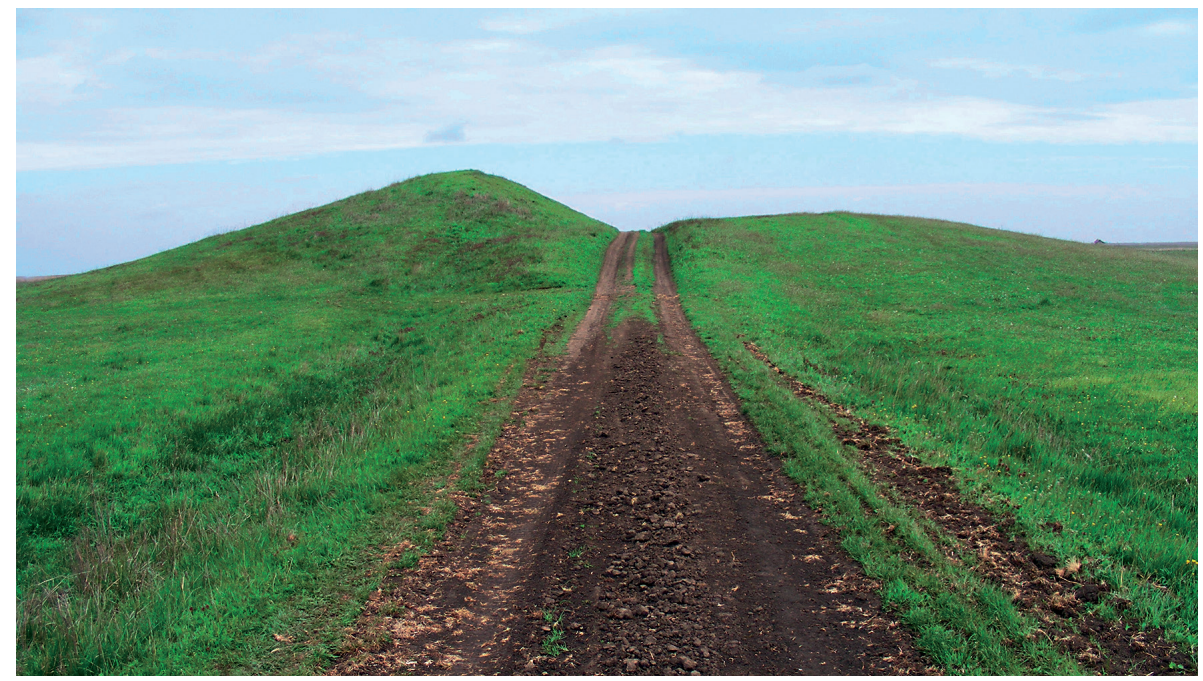

Fig. 2

The Ecse-halom kurgan from the west, spring of 2014 (photo by Á. Bede) 
boreal grassland species, and the area has been used for pastoral herding for several centuries. Pollen and mollusk data suggest that an alkaline wooded steppe environment has been in place for most of the Holocene (Magyari 2011; Sümegi et al. 2013).

Ecse-halom, surrounded by alkaline marshes and meadows, stands on the border between two modern settlements, Karcag and Kunmadaras, within the Hortobágy in Jász-Nagykun-Szolnok County (Fig. 1). A road of medieval origin runs along this border, and cuts deep into the centre of the mound (Fig. 2). The mound was further disturbed during the 20th century: its southern half was plowed and used as a rice field, and a military observation tower was built on top of it. Despite these disturbances, a significant portion of the mound remained intact, and the sediments and other features buried beneath the intact portion remained undisturbed.

\section{Data and methods}

\section{Mapping landscape history}

Handmade maps from the 18th and 19th centuries and modern printed maps provide the primary dataset for the geomorphologic and landscape historical research (list of maps M.1-15). From these sources landscape changes of the last two and a half centuries were documented and mapped. Archived documents were also consulted. Since the Ecse-halom stood on the borderline between two settlements for many centuries, there are documents of border-passing charters available from the Middle Ages and the Early Modern Period, which contained very valuable records not only on the kurgan as a border-point, but the surrounding landscape and land use as well.

\section{Contour mapping}

Topcon (HiPer SR GNSS, FC336 type) high accuracy satellite positioning equipment (RTK) was used to create a contour map of the Ecse-halom and for the field modeling. With the help of this tool it was possible to assess the entire surface of the kurgan and its immediate surroundings (buffer zone) in detail. Data evaluation and editing of the two and three-dimensional geomorphologic field models were carried out using the ArcGIS 10 and AutoCAD Map 3D 2010 programs. It was also possible to reconstruct the status of the kurgan before the 20th century disturbances.

\section{Botanical survey}

Each vegetational patch was documented by phytocoenological (geobotanical) survey to examine the interactions and interrelations between vegetation, climate, topography, soils and anthropogenic impact upon the mound. Samples were collected from $2 \times 2 \mathrm{~m}$ units in seven locations using the Braun-Blanquet approach (Braun-Blanquet 1964). A vegetation map was created from the topographic and bo- 
tanical data, which shows the locations of sampling units. Coverage percentage of the vascular plants was estimated from these sampling units, and a complete list of vascular plants, with attributes of frequency and coverage, was prepared.

\section{Sediment analysis}

Mechanized drilling was carried out at the highest point of the mound. Drilling was carried out by the Hungarian geotechnical engineering company Geovil using a hydraulic rotary-percussion drilling rig with a $10 \mathrm{~cm}$ diameter double-walled pipe for continuous coring with a thin-wall sampler. The complete length of the core was $10 \mathrm{~m} ; 99.7 \%$ of the core was recovered intact. Samples were taken from the core at $8 \mathrm{~cm}$ intervals on average. Altogether, 116 samples were subjected to sedimentological, magnetic susceptibility, soil organic matter and carbonate analyses (Sümegi 2012). In addition, micro-morphological samples were taken from the core. Organic matter and carbonate content determination were based on the loss on ignition (LOI) methods outlined in Dean (1974). Particle size measurements were conducted using an OMEC Easysizer 2.0 laser granulometer. Sediment samples were treated with hydrogen peroxide to disperse clay aggregates prior to analysis. Magnetic susceptibility measurements were taken with a Bartington MS2 meter. The graphic representation of the results was produced using Psimpoll software (Bennett 2005).

\section{Micro-morphology}

Soil micro-morphological analysis was conducted on eight thin sections taken from two sections within the Ecse-halom (Table 1 and Fig. 11). Four samples were analyzed from the upper construction layer, from $250-270 \mathrm{~cm}$ depth, and four other samples were taken to examine the Early Holocene B Horizon, from 550-570 cm depth, because these samples were the most representative and appeared to be suitable for characterization. Prior to their removal, locations to be sampled were examined for provenience, structure, and association with other stratigraphic units. Samples were air dried, impregnated with resin, cut, ground, mounted and polished following the procedures in Murphy (1985). Thin-section slides were examined under plane-polarized and cross-polarized nicols on a petrographic microscope (Páll 2012), and described using accepted terminology (Courty et al. 1989; French 2003; Stoops 2003). Digital images were taken and processed simultaneously with the microscopy work, and were also analyzed.

\section{Results and discussion}

\section{Geomorphology}

The Ecse-halom is a roughly circular kurgan (mound), slightly elongated along its west-east axis, located on an elevated point of the landscape on a remnant surface covered by redeposited Pleistocene loess. 
Table 1

Micro-morphological description of thin-sections from the Ecse-halom kurgan

\begin{tabular}{|c|c|c|c|}
\hline Sample & Depth $(\mathrm{cm})$ & Description & Interpretation \\
\hline $\mathrm{KF}-1$ & $250-255$ & $\begin{array}{l}\text { Cloddy structure; relatively homogeneous, aggregated } \\
\text { particles, poorly sorted; organic remains and snail } \\
\text { shells; clayey edges }\end{array}$ & $\begin{array}{l}\text { Reworked soil deposited } \\
\text { intentionally }\end{array}$ \\
\hline KF-2 & $255-260$ & $\begin{array}{l}\text { Cloddy structure; relatively homogeneous, aggregated } \\
\text { particles, poorly sorted; organic remains and snail } \\
\text { shells; ferrous concretions with sharp boundaries and } \\
\text { diffuse boundaries (3); clayey edges }\end{array}$ & Reworked level \\
\hline $\mathrm{KF}-3$ & $260-265$ & $\begin{array}{l}\text { Compacted cloddy structure; mineral particles, re- } \\
\text { latively homogeneous, aggregated particles, poorly } \\
\text { sorted; organic remains and charred wood fragments; } \\
\text { ferrous concretions with sharp boundaries (4) }\end{array}$ & Reworked level \\
\hline $\mathrm{KF}-4$ & $265-270$ & $\begin{array}{l}\text { Compacted cloddy structure; mineral particles, re- } \\
\text { latively homogeneous, aggregated particles, poorly } \\
\text { sorted; organic remains; iron concretions with sharp } \\
\text { boundaries (4); sparite concretions; } \mathrm{CaCO}_{3} \text { fillings }\end{array}$ & $\begin{array}{l}\text { Redeposited soil with } \\
\text { carbonate concretions }\end{array}$ \\
\hline $\mathrm{KF}-5$ & $550-555$ & $\begin{array}{l}\text { Cloddy structure; relatively homogeneous, aggregated } \\
\text { particles, around the pores or voids; organic remains; } \\
\text { ferrous concretions with sharp boundaries and diffuse } \\
\text { boundaries (5); sparite concretions }\end{array}$ & Buried soil \\
\hline KF-6 & $555-560$ & $\begin{array}{l}\text { Cloddy structure; relatively homogeneous, aggregated } \\
\text { particles, sorted around the pores and the fragments; } \\
\text { organic remains; worm channel fills; ferrous concre- } \\
\text { tions with sharp boundaries and diffuse boundaries, } \\
\text { clay filling (6); sparite concretions; } \mathrm{CaCO}_{3} \text { fillings }\end{array}$ & Buried soil \\
\hline $\mathrm{KF}-7$ & $560-565$ & $\begin{array}{l}\text { Compacted cloddy structure; relatively homogeneous, } \\
\text { aggregated particles, sorted around the pores; organic } \\
\text { remains and large charred wood fragments; ferrous } \\
\text { concretions with sharp boundaries, clay fillings (8); } \\
\text { sparite concretions; } \mathrm{CaCO}_{3} \text { fillings }\end{array}$ & Buried soil \\
\hline KF-8 & $565-570$ & $\begin{array}{l}\text { Cloddy structure; relatively homogeneous, aggregated } \\
\text { particles, sorted around the pores; organic remains; } \\
\text { worm channel fills; ferrous concretions with sharp } \\
\text { boundaries, clay fillings (6); sparite concretions; micrite } \\
\text { concretions; } \mathrm{CaCO}_{3} \text { fillings }\end{array}$ & Buried soil \\
\hline
\end{tabular}

The central coordinates of the Ecse-halom are N47 ${ }^{\circ} 5^{\prime} 31.11^{\prime \prime}$, E20 $57^{\prime} 47.71^{\prime \prime}$ (Google Earth); absolute height: $93.5 \mathrm{~m}$ asl; relative height: $5.5 \mathrm{~m}$; length: $75.5 \mathrm{~m}$, width: $67.5 \mathrm{~m}$. Geomorphologically it shows connections with the loess landscape of the Nagykunság area, particularly the northeastern protrusion of the Nagykunság where it wedges into the Holocene alluvium of the Hortobágy. The mound rises on the eastern end of a slightly elevated, elongated loess ridge that is clearly separable from its surroundings in terms of its vegetation and geomorphology. Floodplain marshes and 


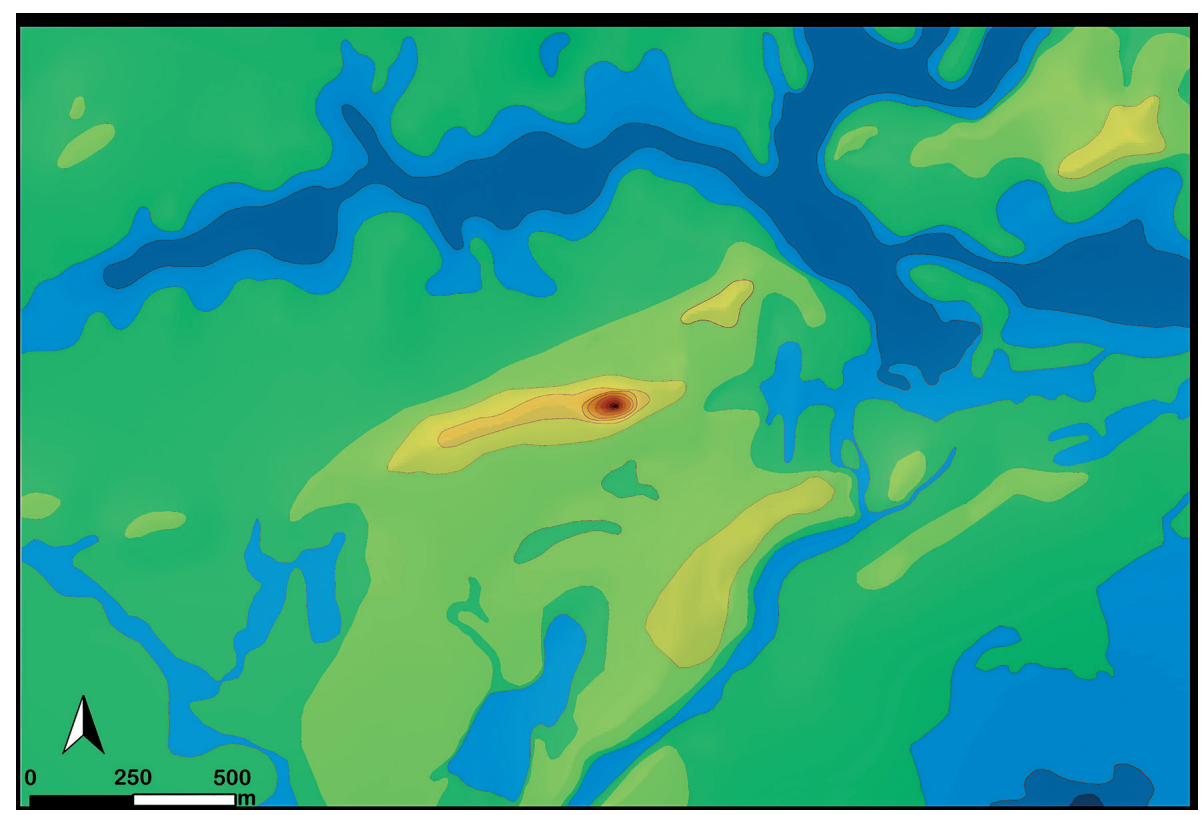

Fig. 3

The Ecse-halom and its vicinity. Dark blue: deep floodplain; light blue: shallow floodplain; dark green: high floodplain; light green: unflooded area; yellow: loess ridge; brown: Ecse-halom kurgan

creek beds that are geohydrologically connected to the rather complex Kunkápolnás marsh system surround this remnant surface (Fig. 3). A ditch that was created when the earth was piled up on the mound is barely detectable around the mound, being most visible on the northwestern and northern edges (Sümegi 2012).

In its geomorphologic and geologic characteristics the Ecse-halom is similar to the Csípö-halom kurgan, also located in the Hortobágy region, near the village of Egyek (Barczi and Joó 2003; Barczi et al. 2006). Its best parallel, however, is $3 \mathrm{~km}$ to the west, also located in the Kunmadaras Plain: the slightly lower and smaller NagyFüves-halom kurgan (Tóth 1988).

\section{Landscape history and contour mapping}

The mound, built by the nomadic Yamnaya people and dated to the Late Copper Age/Early Bronze Age (ca. 3300-2500 BC; Dani and Horváth 2012), has remained visible for nearly 5,000 years and has played a role in local cultural traditions and history.

The first part of the name of the Ecse-halom (eče äčä) is a Cumanian word meaning "sister (mother, woman)" (Baski 2007). Local tradition considers it as a personal name and connects it to a Cumanian warrior named Ecse, who was the owner of the 


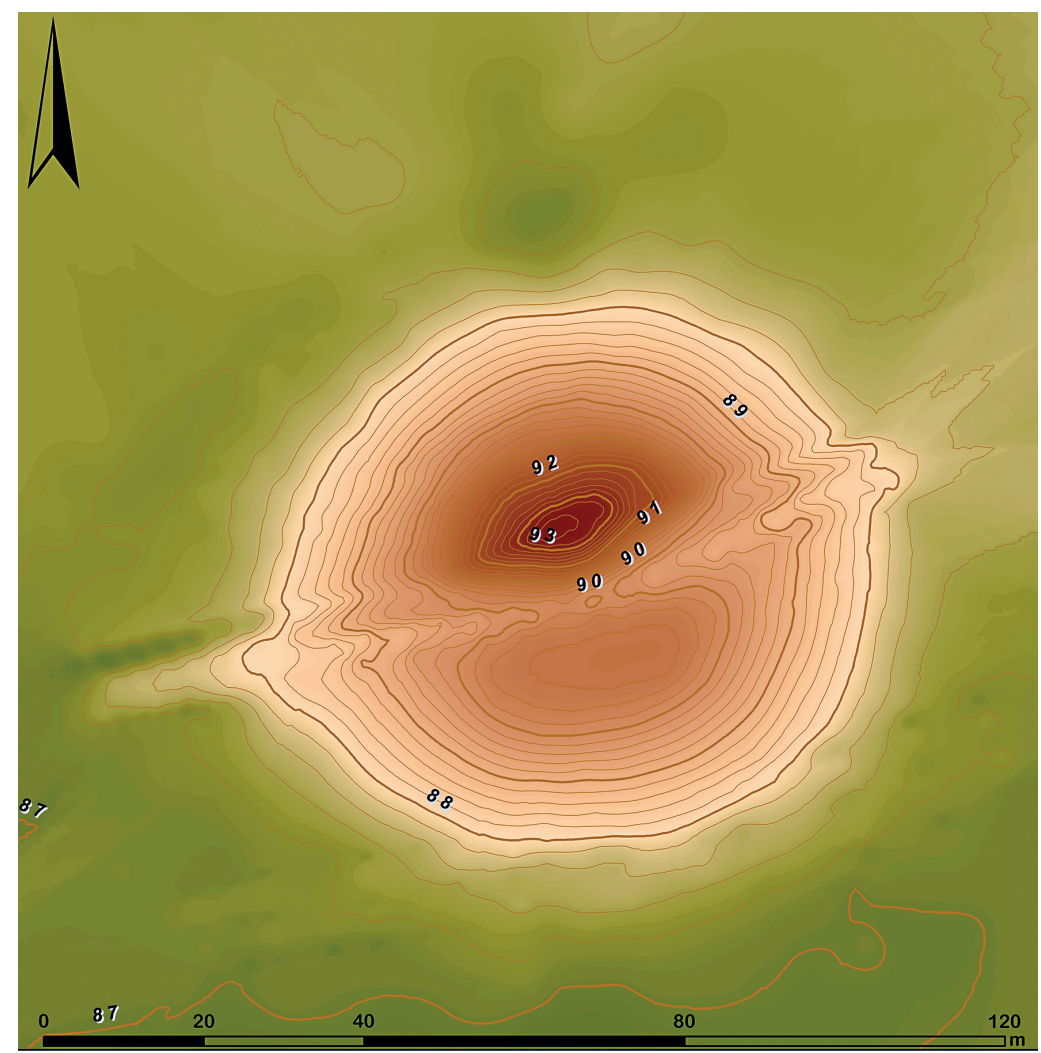

Fig. $4 \mathrm{a}$

Contour map of the Ecse-halom

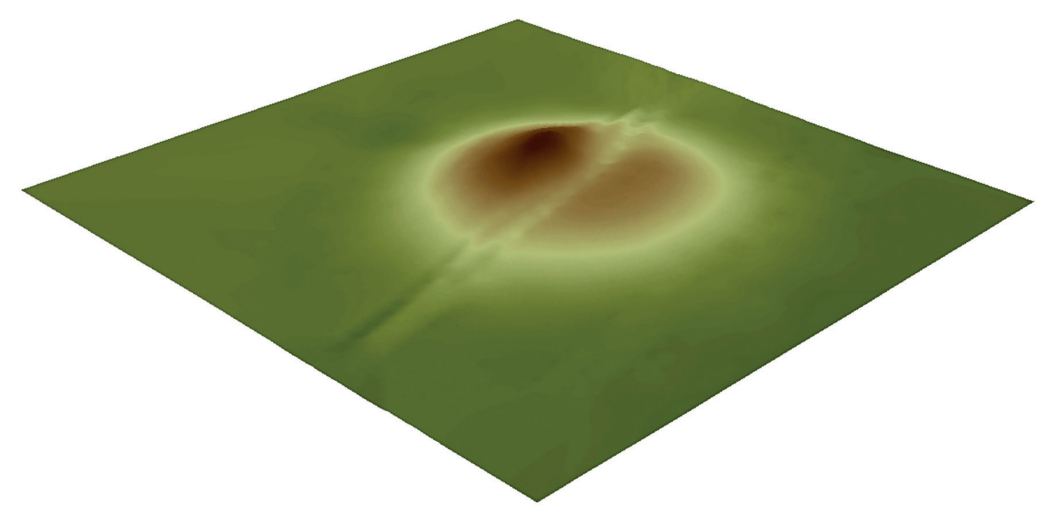

Fig. $4 \mathrm{~b}$

3D bird's-eye view aspect of the Ecse-halom from the southwest 
mound (Györffy 1921; Pesty 1978). The mound is such a salient feature of the landscape that a series of local place names were formed from its name in past centuries. These include Ecse-rét (Ecse meadow; M.3, M.6, M.7), Ecse-róna (Ecse port; M.3), Ecse-zug (Ecse corner; M.5, M.7, M.10), Ecse-fenék (Ecse depth; M.9), Ecse-kút (Ecse fount; M.9), Ecse-háti-tanya (Farm of Ecse Ridge; M.11), Ecse-halmi-major (Grange of Ecse mound; M.12) and Ecse-gát (Ecse barrage; M.12).

The topographical significance of the mound is also shown by the fact that manuscript and printed maps from the 18th century onwards all indicate its position and name: "Ecze halom" (M.1), "Etse halma" (M.2), "Etse Halom" (M.3), "Etse halom" (M.4), "Ecse halom.” (M.5), "Ecse halom” (M.6, M.7), "Ecse-hlm.” (M.8, M.9, M.10, M.11, M.13, M.14, M.15), "Ecsehalom" (M.12). The Ecse-halom kurgan is first mentioned in a charter describing village borders from 1521 (in the form "Echehalma"; Gyárfás 1883; Benedek and Zádor-Zsoldos 1998). In the Early Modern era it was the border point between the villages of Asszonyszállás and Kápolnás. Today it lies on the administrative border between Karcag and Kunmadaras; the borderline breaks at an angle on the tip of the mound.

The most apparent deformation is the dirt road cutting the center of the mound in an east-west direction (Fig. 4a and 4 b). This road was shaped by hundreds of years of use, connecting Kunkápolnás and Nádudvar, and serving local traffic since at least the 16th century (Elek 2008). Due to continuous abrasion and erosion, the road now cuts several meters into the body of the mound (Bukovszki and Tóth 2008). Later on (after the destructions of the Late Ottoman Period) the road lost its significance, although the locals still use it today. The continuation of the road to the east is the Ecse barrage, which enables the crossing of the deeper parts of the Kunkápolnás marsh system. A border ditch, also of medieval origin, is still visible immediately north of the road.

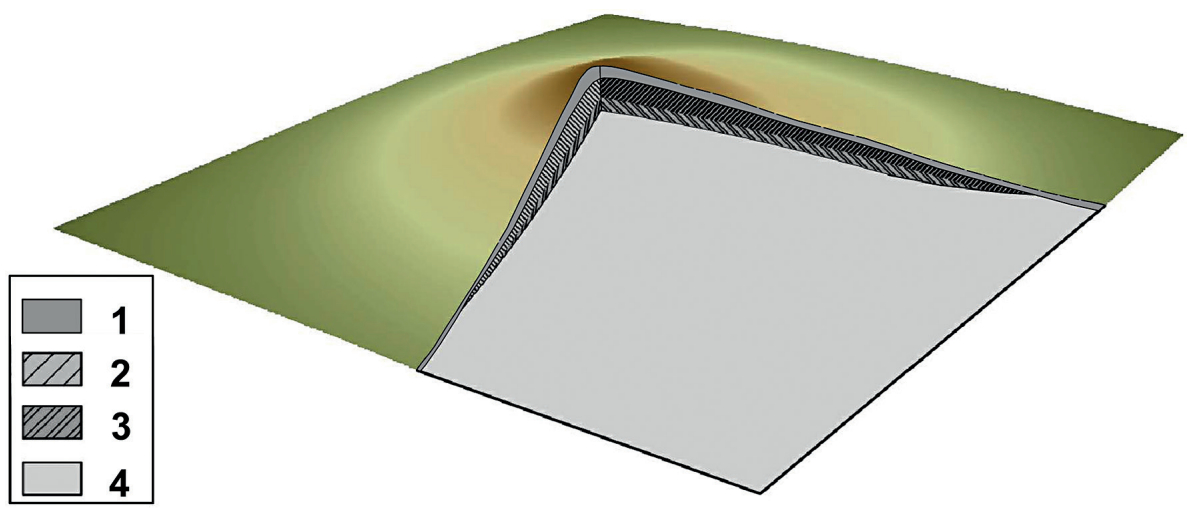

Fig. 5

3D detail section of the reconstructed Ecse-halom. 1: the layer of recent chernozem soil; 2: the second construction layer of the mound; 3: the first construction layer of the mound; 4: the surface of the paleosoil under the mound 
Based on the environment and old maps we may assume that until the 20th century the Ecse-halom was primarily used for animal husbandry (pasture and hay), and no arable farming was carried out in the immediate vicinity (Fig. 6). Manuscript maps from the 18th-19th centuries (M.1, M.2, M.5, M.6) and later printed maps (M.7) consistently represent the whole area of the mound as pasture. In the beginning of the 20th century, however, its southern half was ploughed due to the increased demand for arable land, as depicted on the 1943 map (M.8). Socialist large-scale agriculture and the consequent large-scale landscape transformations did not spare the Ecse-halom: in the 1950s rice parcels were established on its southern side (M.10), traces of which are still visible on the southern periphery of the mound in the form of the parallel dams and embankments. A large amount of soil was removed from the southern side of the mound, and a smaller quantity of soil was removed from the highest part of the northern side as well. In the 1960s the area again served as pasture (M.11). In the wider vicinity of the mound farmsteads, dirt roads, ditches, embankments, grass fields and lower lying swamps can be found.

The mound was used as an observation point to control bombing and shooting practice for the Soviet military shooting range of Kunmadaras. Consequently, a small sentry box was set up on the northern edge of the mound (M.12), and when it was demolished in the second half of the 1980s, a multi-storied, steel-framed observation tower was built on the southern side (Tóth 1988). The tower significantly

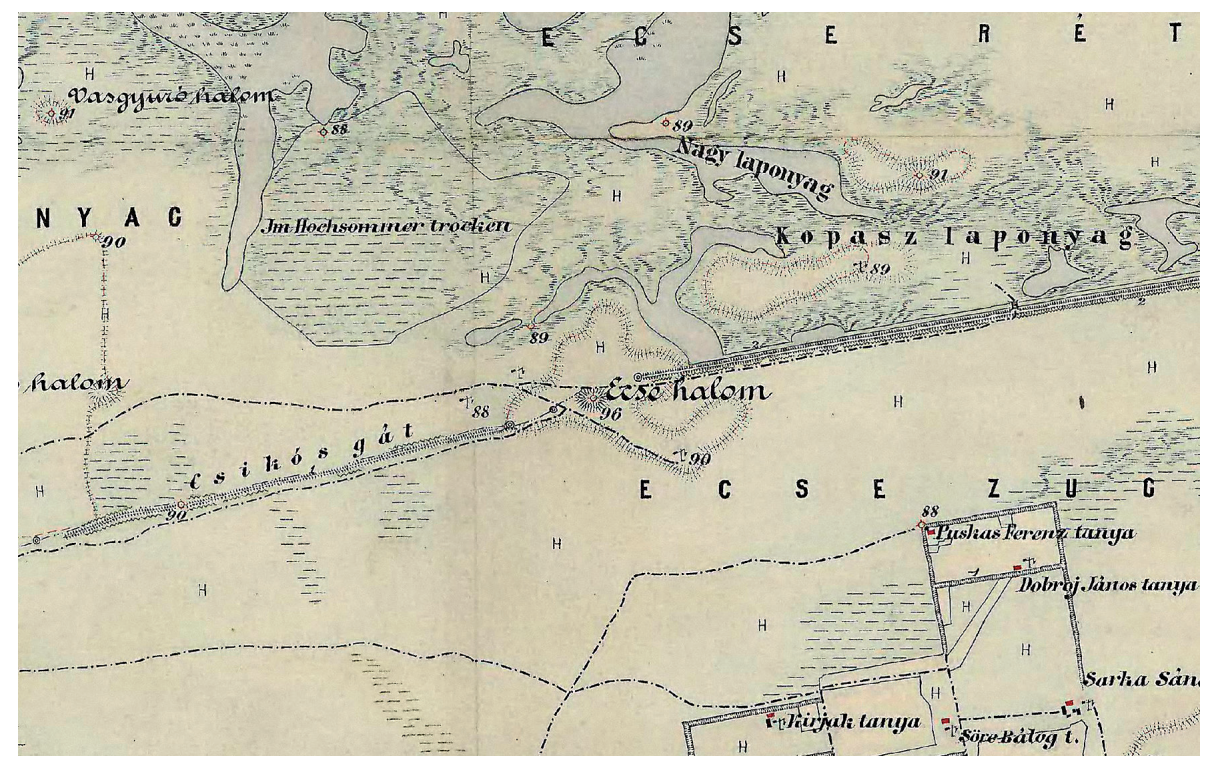

Fig. 6

The Ecse-halom and other mounds in the vicinity on the Third Military Ordnance Map of the Habsburg Empire (M.7, 1883) 
diminished the landscape value of the mound, and was pulled down by the national park directorate after the pullout of the Soviet military. However, its concrete base elements sunk into the mound are still there (Fig. 7), and their removal and disposal is an urgent task. A geologic triangulation point is also set on top of the mound.

\section{Botany}

Approximately 100 vascular plant species have been detected from the kurgan. The flora of the mound is rich in species in a countrywide comparison. Among the attested species are Aegilops cylindrica, Agropyron cristatum, Androsace elongata, Bassia sedoides, Carthamus lanatus, Linaria biebersteinii, Muscari comosum, Ranunculus pedatus, Salvia nemorosa and Verbascum phoeniceum. Although Ecse-halom is not among the most valuable mounds in terms of plant species composition, regionally it certainly represents significant natural value, especially due to the presence of species characteristic for loess steppes.

Because the kurgan rises above its marshy, alkaline environment, a loess steppe association (Salvio nemorosae-Festucetum rupicolae) and its derivative species cover

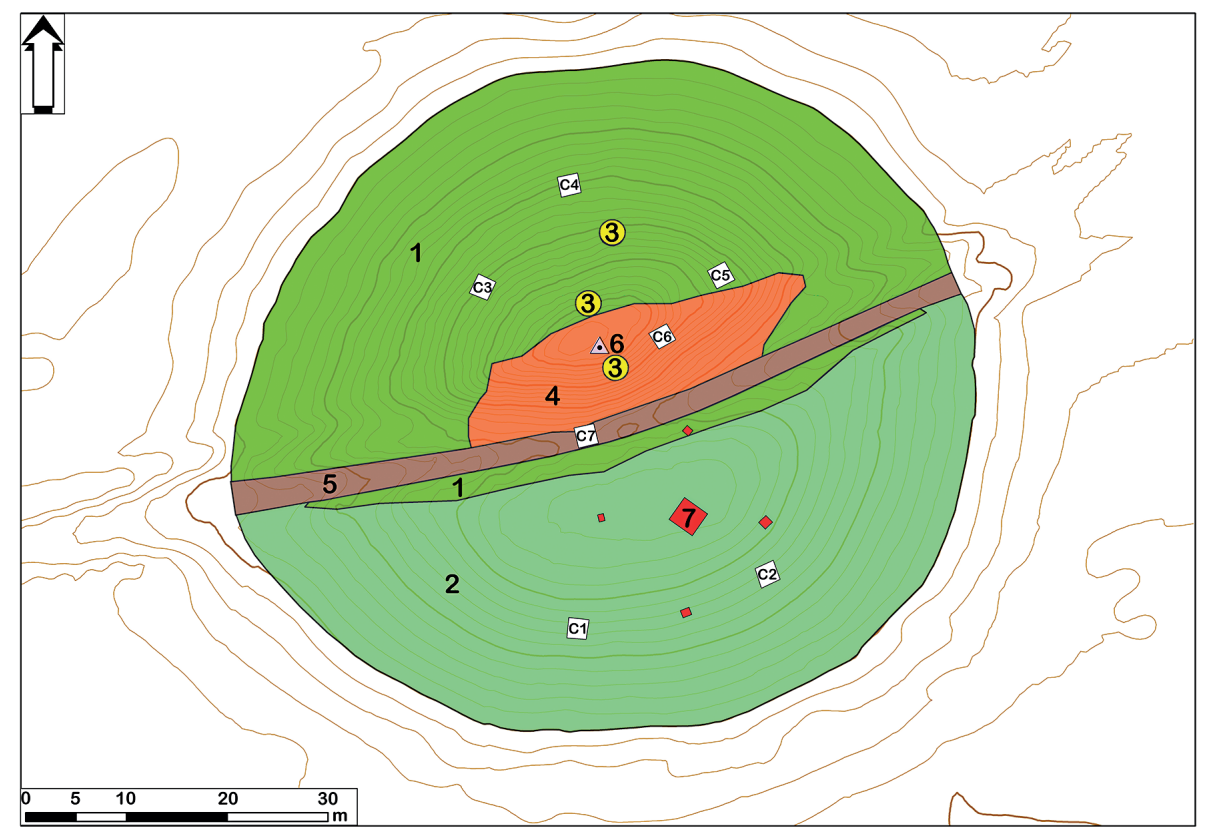

Fig. 7

Vegetation map of the Ecse-halom. 1: loess steppe grassland; 2: uncharacteristic dry grassland with loess steppe grassland elements; 3: population of Agropyron cristatum; 4: quite dry ruderalia with Aegilops cylindrica; 5: dirt road with trampled weeds; 6: triangulation point; 7: concrete elements of the foundation of the military observance tower on the surface; C1-7: coenological samples 
most of its surface (Fig. 7). The mounds are characteristic places of survival of these habitats, and conservationists consider the association to be significant (Joó 2003; Illyés and Bölöni 2007; Horváth et al. 2011). In the northern half of the Ecse-halom, loess steppe can be found in fairly good condition. Agropyron cristatum, characteristic for the dry vegetation of loess bluffs, forms only a few smaller patches on the top and on the northern side. In the southern half of the mound, vegetation is secondary, uncharacteristic dry grassland, a fallow area unplowed for decades. However, even this area contains a few loess steppe species. The steep, south-looking side immediately to the south of the top is covered by dry ruderal species, and is separated from the other vegetational zones by a fairly quite border. Trampled weed associations flank the tracks of the road cutting through the mound in an east-west direction. Arboreal vegetation is only very sparsely present in the area: there is only one small shrub of the species Rosa canina on the kurgan.

In summary, it can be said that the vegetation of the Ecse-halom kurgan is in fairly good condition, partly due to regular but not excessive grazing and mowing.

\section{Sedimentology}

The vegetation and soil characteristics of the mound and its immediate surroundings (extra-local level) are different from the vegetation and soil characteristics at local and regional levels. At a regional level, hydromorphic soils are typical, while at a local level hydromorphic and alkaline soils predominate. The same can be observed in terms of vegetation: marshes, alkaline marshes and wet alkaline meadows dominate at a regional and local level as well in the wider area. Extra-locally, however, a drier type of alkaline meadow and the vegetal elements of loess grassland predominate (Sümegi et al. 2013).

The magnetic susceptibility (MS) values were at a maximum in the lower part of the core, where in some cases they exceeded the value of $100^{*} 10^{-6}$; in contrast, they diminished drastically in the upper layer, between $150 \mathrm{~cm}$ and the surface (Fig. 8). The MS minimum observed in the material of the mound $(420-0 \mathrm{~cm})$ indicates that the mound had been built in two phases. The decrease of magnetic susceptibility values also indicates solution and migration processes; these were observed both in the paleosoil and in the "B" level of the higher, recent soil layer (Fig. 8).

The maximum of organic material content was recorded at the bottom of the column (Fig. 9). The organic content of one sample exceeded 10\%, in others it was around $6-7 \%$. The carbonate content at the same levels, however, was lower. This trend, however, reversed in the layer at $800-780 \mathrm{~cm}$ depth. From $800 \mathrm{~cm}$ on, values for both carbonate and organic content fluctuate. A significant decrease in organic material and an increase in carbonate content were observed in the zone between 150 and $80 \mathrm{~cm}$. The same anomaly was detected in a lower horizon of the core $(570-530 \mathrm{~cm})$. Carbonate values reach their maximum in these levels (Fig. 9). The carbonate content in both cases was located below a level which is characterized by a substantial content of organic matter, typical of chernozem soil humus accumulation zone. The two 


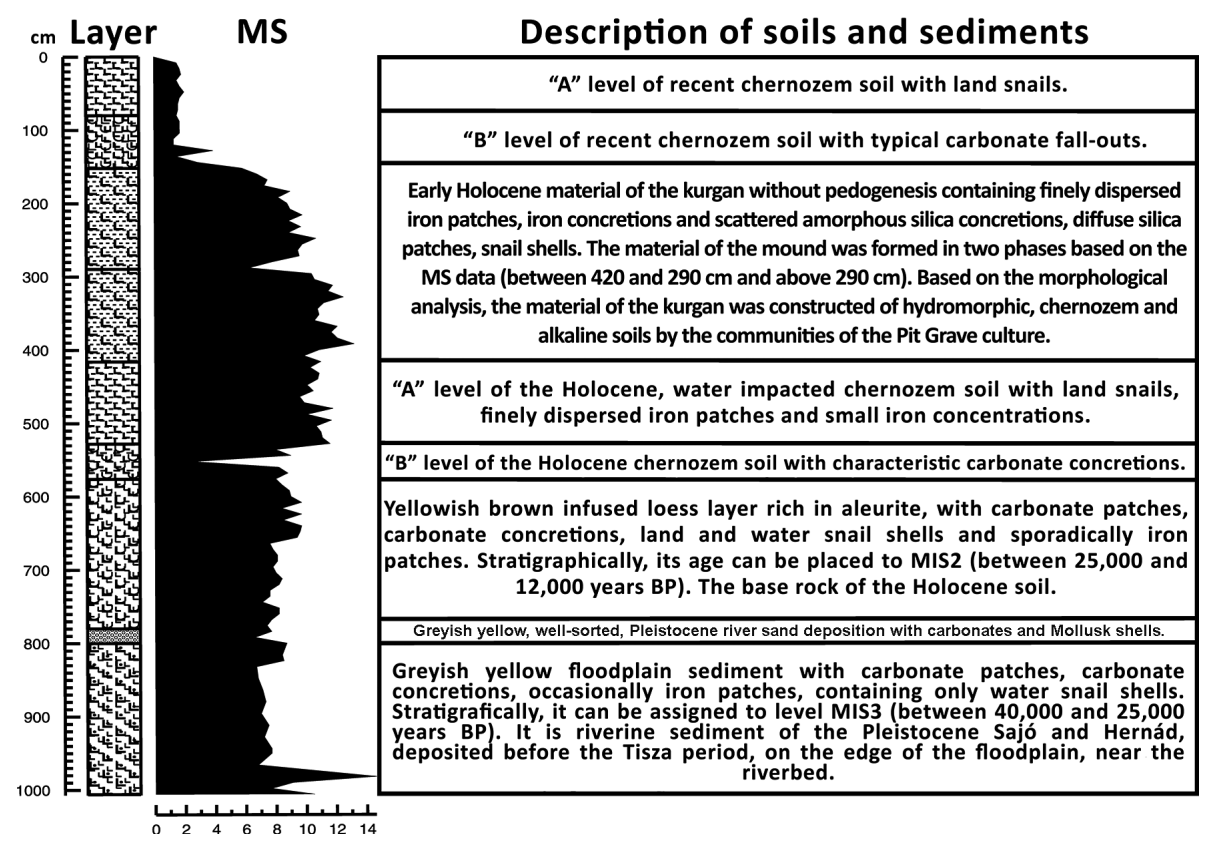

Fig. 8

Stratigraphic sequence, the results of the magnetic susceptibility analysis and the description of the pedogenesis of the core in the Ecse-halom kurgan

levels of formation can be explained - based on the soil science literature (Duchaufour 1998; Schmidt et al. 2002; Stefanovics et al. 2010) - by accumulation of humus and carbonate dissolution in the upper level, and spin-off of carbonate in the deeper "B" level. The humus levels are relatively poor in carbonate, while levels below them are relatively richer therein. Carbonate migration into the deeper level is explained by dissolution. Therefore the levels containing carbonate precipitates, concretions and stains below the rich humus levels were formed as a result of dissolution, migration and precipitation.

The distribution of grain size is uniform throughout the entire core. Mid-grained siltstone fraction $(0.016-0.031 \mathrm{~mm}$ in size) appears in the largest quantities. Large deviations from these values were only detected in a few points of the core, particularly at $800-780 \mathrm{~cm}$ and at 100-90 cm (Fig. 10). Between 800 and $780 \mathrm{~cm}$ characteristic river soil colonization occurred within the series of actively developing alluvial sediments; therefore a coarser-grained sandy sediment appeared. Between 100 and $90 \mathrm{~cm}$ daub debris appeared, as what was classified as a fine sand fraction, an indication that human activity affected the mound at this level.

Based on the macroscopic description, sedimentary facies features, geoarcheological characteristics and magnetic susceptibility data of the core, the following 

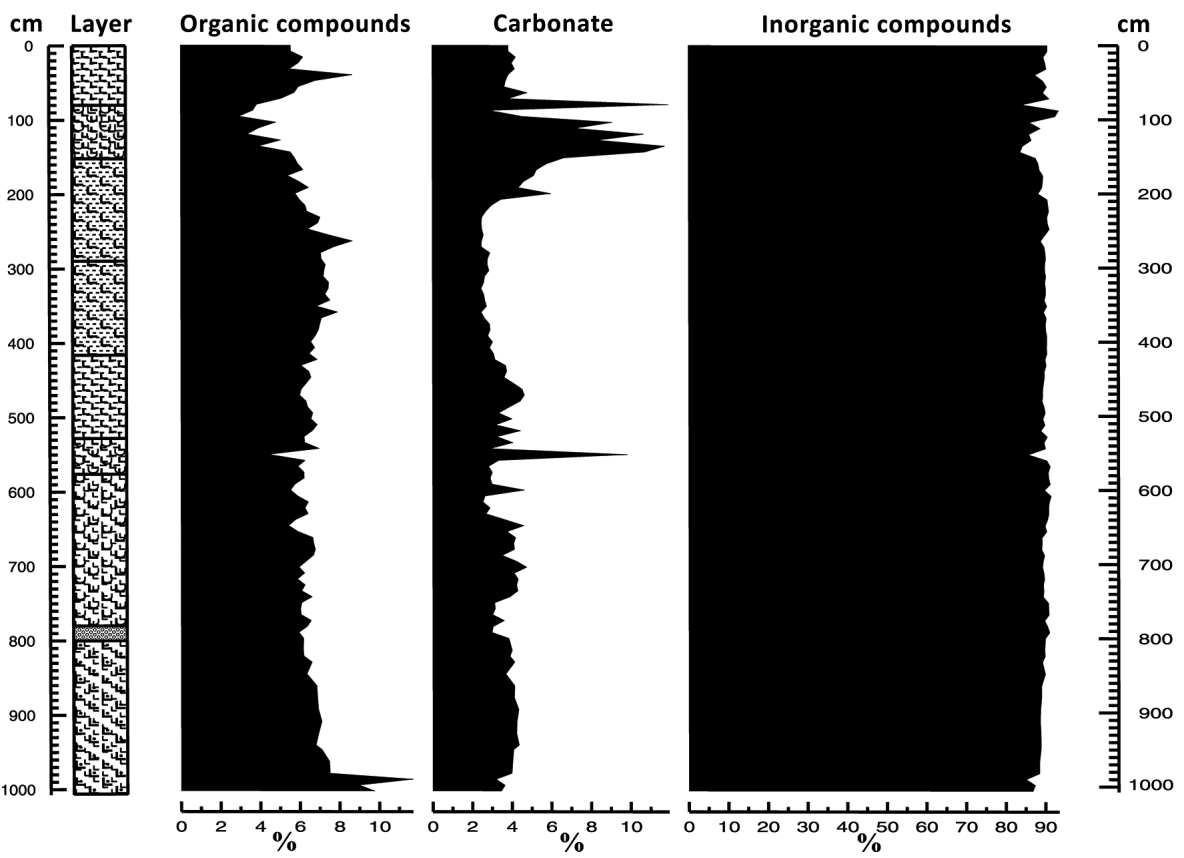

Fig. 9

Stratigraphic sequence of the core in the Ecse-halom and the results of the study of organic, carbonate and inorganic material contents

layers, genetic levels and consequently natural and anthropogenic processes could be identified (Fig. 8).

The bottom of the core column, at $1006-800 \mathrm{~cm}$ depth, is composed of unsorted, clayey silt which is probably a floodplain sediment. Based on its carbonate content the sediment is the result of the activity of the Sajo and Hernád Rivers that played a primary role in the formation of the local terrain during the Pleistocene.

At $800-780 \mathrm{~cm}$ depth a thin layer is found, consisting of well-sorted fluvial sand that is also derived from the alluvium of the Sajó-Hernád river system. This is indicated by the data on grain composition and carbonate content, and mollusk shell fragments.

The layer between 780 and $570 \mathrm{~cm}$ is composed of yellowish-brown redeposited loess formed in the second half of the Pleistocene, consisting of fine and coarse silt fraction. This corresponds to loess sediments found in other areas of the Hortobágy. Its age can be placed between 25,000 and 12,000 years, and it forms part of the Holocene substratum (Rónai 1985; Nyilas and Sümegi 1991).

An Early Holocene paleosol is identified between 570-420 cm depth. The lower part of this paleosol $(570-530 \mathrm{~cm})$ is characterized by high carbonate content and low MS values. The upper part of the paleosol can be found in the section between 530- 


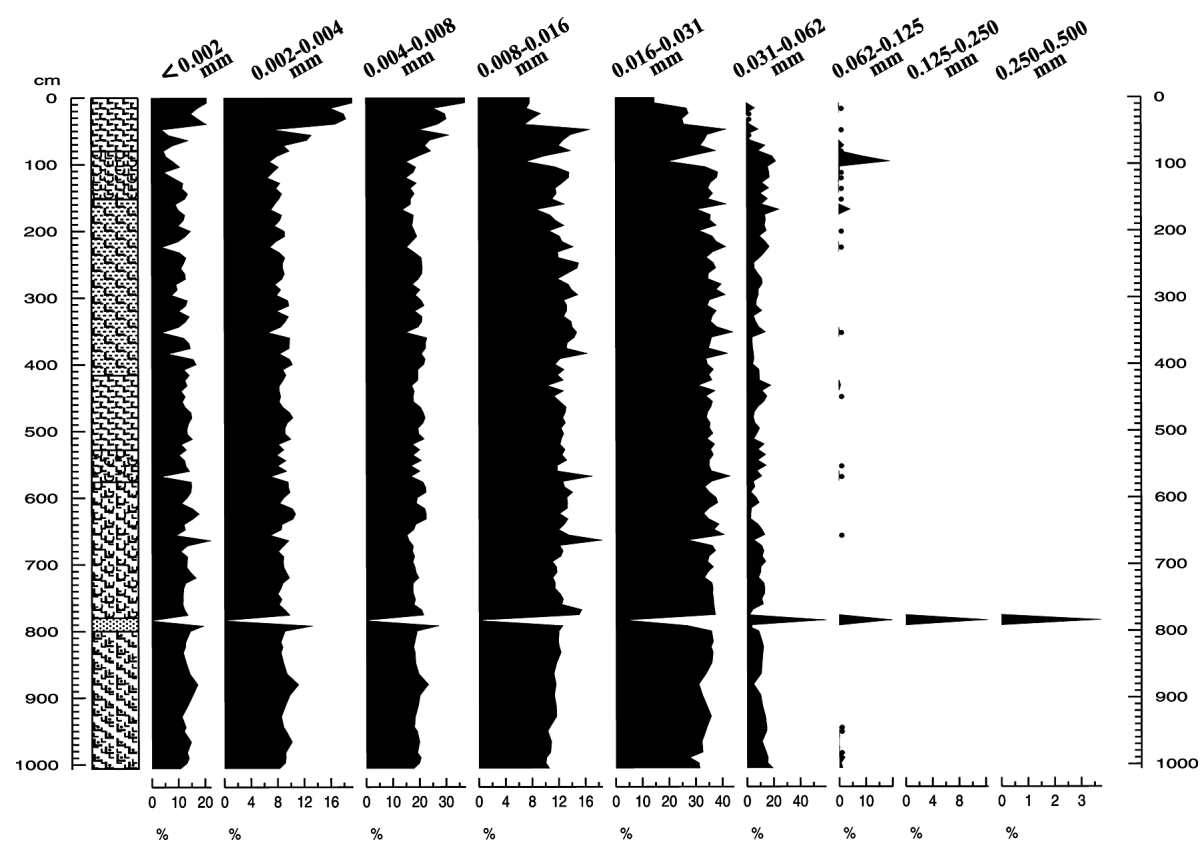

Fig. 10

Stratigraphic sequence of the core in the Ecse-halom and the results of laser sedigraph analysis of the samples

$420 \mathrm{~cm}$. Based on the macroscopically observable traits (e.g. polyhedral structure, iron hydroxide spots and grains) the paleosol was categorized as meadow chernozem.

The main body of the kurgan, representing the construction of the mound, rises from 420-140 cm and comprises two major layers which are located upon each other. The first, earlier layer is $1.3 \mathrm{~m}$ thick and the second construction layer is $1.5 \mathrm{~m}$ thick (Fig. 5). Magnetic susceptibility values in the main body of the mound are nearly identical to those of the upper part of the Early Holocene paleosol, and are rich in organic matter (Figs 8 and 9). Nevertheless, it was possible to detect a change in the MS value at $290 \mathrm{~cm}$ depth, indicating the movement of elements and solution, suggesting a long-term open surface. Based on this data, the Late Copper Age/Early Bronze Age Yamnaya community probably raised the mound in two phases (Fig. 5). The first phase is found between the depth of 420 and $290 \mathrm{~cm}$. The two mound-building horizons are separated by a short hiatus not longer than one or two generations (30-50 years), since no carbonate content could be observed in the lower layer, indicating that carbonate movement had not started and become intensive on the surface of the lower kurgan surface. The second phase extends from 290-140 cm. It cannot be excluded that the two building phases are connected to two major burials, but this can only be confirmed by complete excavation of the mound. 
Carbonate, ferrous and alkaline patches were identified in the soil of the original kurgan body. The part of the mound above $140 \mathrm{~cm}$ depth is covered by a very dark grey-brown chernozem formed during the past 4000 years, which is the pedogenic version of the material of the kurgan. However, due to the protrusion of the anthropogenic surface, it was formed in a stable and drier steppe environment as compared to the Early Holocene soil. Significant change in carbonate and organic material content was detected only on the surface of the kurgan: the significant organic material content in the upper part of this chernozem soil formed on the island-like protrusion of the surface of the kurgan, while in the lower part, a horizon rich in well-developed carbonates was formed. The formation of both horizons indicates an intensive formation of prairie soil following the creation of the kurgan. The raised geomorphologic position, the relatively dry relief in the aqueous environment, and the climatic conditions of the past 4000 years have played a significant role in the formation of the recent prairie soil covering the surface of the kurgan (Sümegi 2012).

\section{Micro-morphology}

Three larger layers could be differentiated in the body of the kurgan; two anthropogenic construction layers and a young pedogenic layer. The paleosol, the original Holocene soil on top of which the mound was built, includes a remnant A-horizon over a B-horizon containing larger sediment grains and with low organic material content (Fig. 11).

The uppermost part of the mound contains recent soils that reflect soil development and the current state of the local area. In comparison, the middle part (samples KF1-4), which had been redeposited as a result of anthropogenic impact, occasionally shows loess-like characteristics (Table 1). The carbonate content is sometimes elevated in the sediments in the immediate environment of the mound, and occasionally calcareous shells could be detected in the sections (e.g. samples KF-1, KF-2; Fig. 12/4).

Above the paleosol with low organic matter content (in the inner part of the kurgan) a layer with low carbonate content can be found, the grain composition of which is different from that of both its covering and underlying layers. This layer - found in the $550-570 \mathrm{~cm}$ section - is contemporaneous with the construction of the kurgan, and is covered by a redeposited, loess-like sediment. The micro-morphological traits and shells in the soil layer provide information on the coeval environment and external impacts (Fig. 12). Numerous charred wood remains occur in the thin sections, resulting from burial activities preceding the construction of the kurgan. The layer, however, is exempt of recent impacts. This is confirmed by the fill of the voids found in the thin sections, the material of which is calcareous, and were filled after small-scale biological activities, e.g. borings by worms (Becze-Deák et al. 1997). Based on the current position of calcareous concentrations and the character of the fill of the voids, the soil buried due to anthropogenic impact must have been meadow chernozem. The number of ferrous inclusions indicating inactive impacts is higher, which characterizes the earlier environment of the area, and shows the duration of water coverage (Páll 2012). 


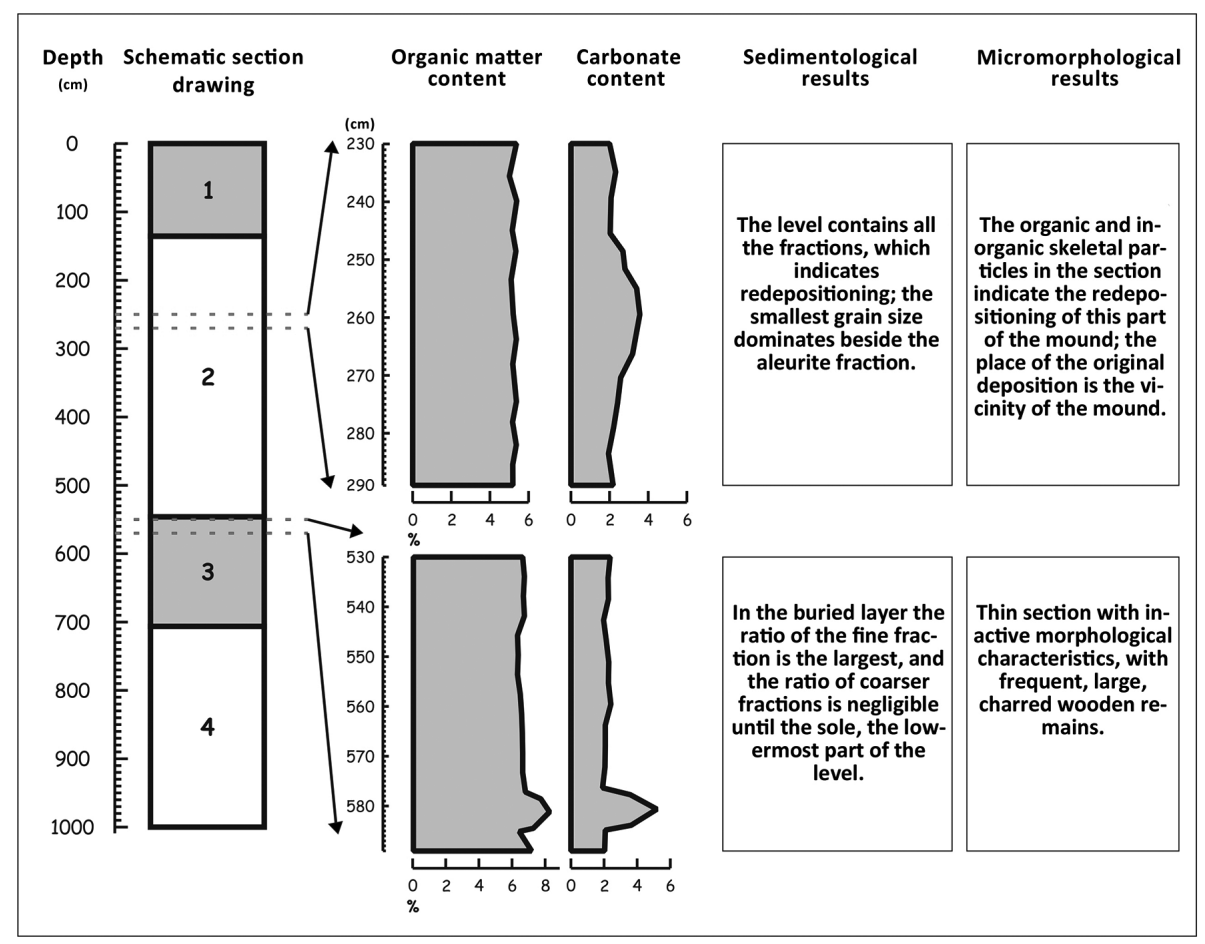

Fig. 11

Organic material and carbonate content (\%) of the sediments from the mound and the comparison of the results of the sedimentological and micro-morphological analyses

\section{Conclusions}

Despite disturbance by plowing and the military observation tower, sediments below the mound are well preserved. The kurgan comprises two construction layers as indicated by the decrease of magnetic susceptibility and varying values for organic compounds and carbonate content. These interpretations are supported by thin-section analysis. Carbonate, ferrous and alkaline patches were identified in the soil of the kurgan, which indicate that the kurgan was formed from three types of soil: hydromorphic, alkaline and prairie. These soils may have formed a hydroseries in the region, of marshlands, seasonally inundated salt meadows and better-drained grasslands. The majority of the kurgan is composed of prairie soils, which probably dominated the immediate vicinity of the kurgan in the middle Holocene, although hydromorphic soils must have occurred in nearby marshy areas. The shallow hollow observed in a $100 \mathrm{~m}$ radius around the mound was likely formed during the collection of the soil for the mound. 


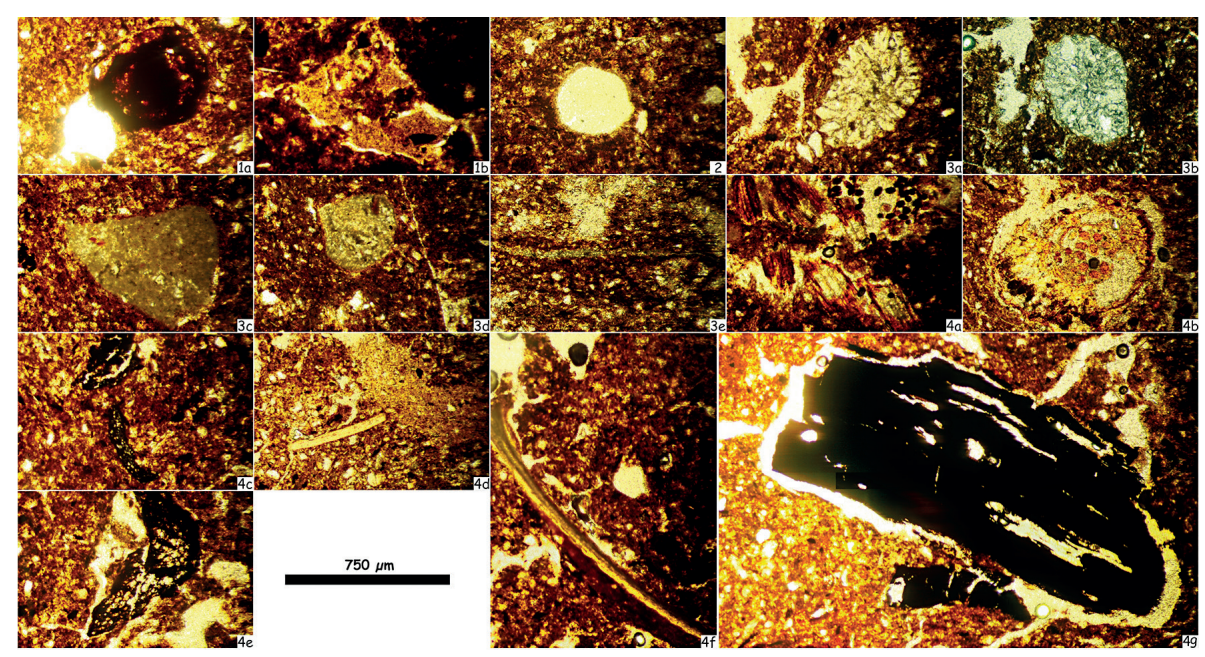

\section{Fig. 12}

Micrographs of typical constituents of Ecse-halom materials in thin sections. 1a-1b (sample KF-5): ferrous concretions in the sections; 2 (sample KF-6): void; 3a-3e (sample KF-7): calcareous concretions and skeletal particles of various size and appearance (in $3 \mathrm{a}-3 \mathrm{~b}$ with calcified root cells from the buried horizon); 4a-4g (sample KF-8): skeletal particles of various size and form in the thin sections (excretions, parts of the soil; root remains, these particles of the soil are more stable; snail shells, these are organic or inorganic materials; charred wood remains, which are bigger and more stable than the aggregates)

The micro-morphological analysis of the thin-sections clearly demonstrated that the levels of accumulation of the original habitat are not present; they were deposited under different conditions with anthropologenic effects. The layers originate from the immediate vicinity of the mound, but due to local diachronic environmental changes, they have different characteristics than present-day soils. The thin sections from the lower parts of the section indicate that the buried soil is a meadow chernozem, whilst the recent soil from the immediate surroundings is meadow solonetz.

The presence of multiple soil types in the construction fill, including hydromorphic soils expected from the surrounding area but not from the immediate vicinity of the mound, is most likely the result of expediency. The presence of two clearly defined construction episodes has been found at other mounds from this period, including the Lyukas-halom kurgan in northeast Hungary (Barczi et al. 2009), but in other cases, such as the Csípő-halom mound in the Hortobágy, only one construction episode is evident (Barczi et al. 2009). The reasons for these differences are not clear, but since both single- and double-layered mounds occur in the Hortobágy region, it is unlikely that local cultural preferences were responsible. Developing a catalog of the different mound types and investigating the cultural and environmental conditions of these variants is one goal of our long-term project.

The surface of the Ecse-halom kurgan is in a decent condition and provides a home for a regionally significant, species-rich loess steppe grass. Many burial mounds 
maintain ancient loess-vegetation on their surfaces, as found in a large survey of Ukrainian mounds (Sudnik-Wójcikowska et al. 2011), but others (e.g. the Lyukas-halom kurgan; Petö et al. 2010) do not.

Although these burial mounds are recognized as important features of the Hungarian landscape, and indeed the plain landscapes of much of Eurasia, relatively little information has been collected from them until recently. The mounds are an important cultural heritage, marking the activities of past communities, and contain a wealth of information about the cultures that built them. Until recently, archaeological excavations have focused largely on the collection of portable artifacts and skeletal remains. Equally importantly, however, the mounds represent an indispensable soil archive holding paleoenvironmental data dating back several thousand years. Each mound contains valuable information regarding local geoarcheology, ethnology, history, botany, zoology, pedology and hydrology. Burial mounds from different periods, e.g. Bronze Age, early Iron Age, Roman and the Migration Period, can be compared, as each will retain a record of local environment and anthropogenic impact for its era. Likewise, mounds from different regions, e.g. Hungary and Ukraine, west and east of the Carpathians, can be compared for regional differences. Research into historical perceptions and use of the mounds can also contribute to onomastics.

Due to constant agricultural cultivation, most of the mounds in the Hortobágy and Tiszántúl areas are endangered. Many have permanently disappeared, and those remaining are always at risk of destruction. Therefore, if the kurgans cannot all be protected, immediate action is required to perform scientific data collections, surveys and cadasters to preserve the cultural and environmental data contained within these earthen monuments. Surveying and protection is our common goal, which needs precise, reliable scientific research work. Our research plan is the thorough surveying of the mounds in the Tiszántúl and Hortobágy region, establishing a strategy for their protection, and comprehensive data collection for those mounds that are being destroyed.

\section{Acknowledgements}

We thank the Hortobágy National Park Directorate, Debrecen, Hungary for supporting this project. Pál Sümegi was supported by the European Union and the State of Hungary, co-financed by the European Social Fund in the framework of TÁMOP4.2.4.A/2-11/1-2012-0001 "National Excellence Program". Special thanks go to the management of Móra Ferenc Múzeum, Szeged, Hungary.

\section{Maps}

M.1: First Military Ordnance Map of the Habsburg Empire, 1783, 1:28,800, C.XXII. S.XX. Institute and Museum of Military History, Budapest.

M.2: "Geometrica delineatio totius terreni privilegiati oppidi Cumanicalis Kartzag Uj Szállás", 17841787, 1:40,000, Kováts, Gy. Archives of Jász-Nagykun-Szolnok County, T.300. 
M.3: Territory of Kunmadaras (Ecse meadow), 1788, 1:14,400. Archives of Jász-Nagykun-Szolnok County, T.95.

M.4: Regulational plan of Berettyó River and Nagy-Sárrét meadow, 1794, 1:86,400, Gasner, L. National Archives of Hungary, S12. XI.132.

M.5: “A Nagy Kun Karczagi Határ Átnézeti Térképe” (Overview Map of Karcag in the Greater Cumania), 1859, 1:28,800. Archives of Jász-Nagykun-Szolnok County, T.166.

M.6: Second Military Ordnance Map of the Habsburg Empire, 1861, 1:28,800, S.50. C. XL. Institute and Museum of Military History, Budapest.

M.7: Third Military Ordnance Map of the Habsburg Empire, 1883, 1:25,000, 5066/1. Institute and Museum of Military History, Budapest.

M.8: Military Ordnance Map of the Hungarian Kingdom, 1943, 1:50,000, 5066 NY. Institute and Museum of Military History, Budapest.

M.9: Military Ordnance Map of Hungary, 1952, 1:25,000, L-34-18-D-b. Institute and Museum of Military History, Budapest.

M.10: Military Ordnance Map of Hungary, 1956, 1:25,000, L-34-18-D-b. Institute and Museum of Military History, Budapest.

M.11: Military Ordnance Map of Hungary, 1966-1967, 1:10,000, 409-424. Institute and Museum of Military History, Budapest.

M.12: Topographical Map (Hungarian uniform map system), 1977, 1:10,000, 68-413.

M.13: Military Ordnance Map of Hungary, 1980, 1:25,000, L-34-18-D-b. Institute and Museum of Military History, Budapest.

M.14: Military Ordnance Map of Hungary, 1991, 1:25,000, L-34-18-D-b. Institute and Museum of Military History, Budapest.

M.15: Military Ordnance Map of Hungary, 2003, 1:50,000, L-34-18-D. Institute and Museum of Military History, Budapest.

\section{References}

Anthony, D.W. 2007: Horse, the Wheel and Language. How Bronze-Age Riders from the Eurasian Steppes Shaped the Modern World. - Princeton University Press, Princeton, Oxford, 576 p.

Barczi, A., K. Joó 2003: Pedological studies on Csípő-halom (mound) in Hortobágy (Hungary). Földrajzi Értesítő, 52, pp. 37-45.

Barczi, A., T. M. Tóth, A. Csanádi, P. Sümegi, I. Czinkota 2006: Reconstruction of the paleoenvironment and soil evolution of the Csípö-halom kurgan, Hungary. - Quaternary International, 155-156, pp. 49-59.

Barczi, A., A. Golyeva, Á. Pető 2009: Palaeoenvironmental reconstruction of Hungarian kurgans on the basis of the examination of palaeosoils and phytolith analysis. - Quaternary International, 193, pp. 49-60.

Barczi, A., K. Penksza, K. Joó 2011: Soil-plant associations on kurgans of the Great Hungarian Plain. Agrokémia és Talajtan, 60, pp. 293-304.

Baski, I. 2007: Csagircsa. Török és magyar névtani tanulmányok. 1981-2006 (Csagircsa. Onomatic studies about the Hungarian and Turkish names. 1981-2006). - Kunszövetség, Karcag, 320 p. (in Hungarian)

Becze-Deák, J., R. Langohr, E.P. Verrecchia 1997: Small scale secondary $\mathrm{CaCO}_{3}$ accumulations in selected sections of the European loess belt. Morphological forms and potential for paleoenvironmental reconstruction. - Geoderma, 76, pp. 221-252.

Benedek, Gy., M. Zádor-Zsoldos 1998: Jász-Nagykun-Szolnok megyei oklevelek. 1075-1526 (Charters from Jász-Nagykun-Szolnok County. 1075-1526). - Jász-Nagykun-Szolnok Megyei Levéltár, Szolnok, 317 p. (in Hungarian) 
Bennett, K.D. 2005: Psimpoll and pscomb. - http://www.kv.geo.uu.se/psimpoll.html.

Braun-Blanquet, J. 1964: Pflanzensoziologie. Grundzüge der Vegetationskunde. (3. Auflage). - Springer Verlag, Wien, $865 \mathrm{p}$.

Bukovszki, J., Cs. Tóth 2008: Changes in the state of Cumanian mounds lying in the vicinity of Karcag from the end of the 18th century till today. - Acta Geographica ac Geologica et Meteorologica Debrecina (Geology, Geomorphology, Physical Geography Series), 3, pp. 145-153.

Courty, M.A., P. Goldberg, R.I. Macphail 1989: Soils and Micromorphology in Archaeology.-Cambridge University Press, Cambridge, $344 \mathrm{p}$.

Dani, J., T. Horváth 2012: Öskori kurgánok a magyar Alföldön. A Gödörsíros (Jamnaja) entitás magyarországi kutatása az elmúlt 30 év során. Áttekintés és revízió (Ancient kurgans on the Great Hungarian Plain. The research of the pit grave (Yamnaya) entity in the last 30 years in Hungary. Survey and revision). - Archaeolingua Alapítvány, Budapest, 215 p. (in Hungarian)

Dean, W.E. 1974: Determination of the carbonate and organic matter in calcareous sediments and sedimentary rocks by loss on ignitions: comparison with order methods. - Journal of Sedimentary Petrology, 44, pp. 242-248.

Duchaufour, P. 1998: Handbook of Pedology. Soils, Vegetation, Environment. - A. A. Balkema, Rotterdam, $264 \mathrm{p}$.

Ecsedy, I. 1979: The People of the Pit-Grave Kurgans in Eastern Hungary. Fontes Archaeologici Hungariae. - Akadémiai Kiadó, Budapest, pp. 1-85.

Elek, Gy. 2008: Várostörténet ötvenkét tételben. Karcag város története 1506-1950 között, (Town history in fifty-two heading. The history of Karcag town between 1506 and 1950). - Karcagi Nyomda Kft., Karcag, 199 p. (in Hungarian)

French, C.A.I. 2003: Geoarchaeology in Action: Studies in Soil Micromorphology and Landscape Evolution. - Routledge, London/New York, 291 p.

Gyárfás, I. 1883: A jász-kúnok története III. (The history of Jazyg and Cumanian people III.). - private printing, Szolnok, 795 p. (in Hungarian)

Győrffy, I. 1921: Kunhalmok és telephelyek a karczagi határban (Cumanian mounds and settlements in the township of Karcag). - Föld és Ember, 1, pp. 59-62. (in Hungarian)

Horváth, A., E. Illyés, Zs. Molnár, Cs. Molnár, A.I. Csathó, S. Bartha, A. Kun, I.J. Türke, I. Bagi, J. Bölöni 2011: H5a. Löszgyepek, kötött talajú sztyeprétek (Closed steppes on loess). - In: Bölöni, J., Zs. Molnár, A. Kun (Eds): Magyarország élőhelyei. Vegetációtípusok leírása és határozója, ÁNÉR 2011. MTA Ökológiai és Botanikai Kutatóintézete, Vácrátót, pp. 174-181. (in Hungarian)

Horváth, T. 2011: Hajdúnánás-Tedej-Lyukas-halom. An interdisciplinary survey of a typical kurgan from the Great Hungarian Plain region: a case study (The revision of the kurgans from the territory of Hungary). - In: Pető, Á., A. Barczi (Eds): Kurgan Studies. An Environmental and Archaeological Multiproxy Study of Burial Mounds in the Eurasian Steppe Zone. British Archaeological Reports, International Series 2238, Archaeopress, Oxford, pp. 71-131.

Illyés, E., J. Bölöni (Eds) 2007: Slope Steppes, Loess Steppes and Forest Steppe Meadows in Hungary. - private printing, Budapest, $234 \mathrm{p}$.

Joó, K. 2003: Researches on kurgans (the vegetation of Csípő-mound). - Tájökológiai Lapok, 1, pp. $87-96$.

Magyari, E. 2011: Late quaternary vegetation history in the Hortobágy Steppe and Middle Tisza Floodplain, NE Hungary. - Studia Botanica Hungarica, 42, pp. 185-203.

Molnár, S., P. Sümegi 2007: A long history of the Kiri-tó meander. - In: Whittle, A. (Ed): The Early Neolithic on the Great Hungarian Plain. Investigations of the Körös Culture Site of Ecsegfalva 23, County Békés. Varia Archaeologica Hungarica, 21, pp. 47-66.

Murphy, C.P. 1985: Thin section preparation of soils and sediments. - A B Academic Publishers, Berkhamsted, $149 \mathrm{p}$.

Nyilas, I., P. Sümegi 1991: The Mollusc fauna of Hortobágy at the end of the Pleistocene (Würm3) and in the Holocene. - In: Meier-Brook, C. (Ed): Proceeding of the Tenth International Malacological Congress, Tübingen, 1989, pp. 481-486. 
Páll, D.G. 2012: Löszös alapkőzetű, eltérő genetikájú fosszilis talajok mikromorfológiai meghatározása és értékelése a Kárpát-medencében (Micromorphological analysis of selected palesol samples of variable genetics on loessy bedrock in the Carpathian Basin). - PhD dissertation, University of Szeged, Dept. of Geology and Paleontology, 138 p. (in Hungarian)

Pesty, F. 1978: Kéziratos helynévtárából I. Jászkunság (Manuscript place name archives I. Jászkunság). - Katona József Megyei Könyvtár, Verseghy Ferenc Megyei Könyvtár, Kecskemét-Szolnok, 406 p. (in Hungarian)

Pető, Á., A. Barczi (Eds) 2011: Kurgan Studies. An environmental and archaeological multiproxy study of burial mounds in the Eurasian steppe zone. - British Archaeological Reports, International Series $2238,350 \mathrm{p}$.

Pető, Á., T. Bucsi, Cs. Centeri, A. Barczi 2010: Reconstruction of past environments based on pedological, micromorphological and phytolith analyses. - In: Gilkes, R., N. Prakongkep (Eds): 19th World Congress of Soil Science 2010 Australian Society of Soil Science, Brisbane, pp. 19-22.

Rónai, A. 1985: The quaternary of the Great Hungarian Plain. - Geologica Hungarica Series Geologica, $21,445 \mathrm{p}$.

Salisbury, R.B., G. Bácsmegi, P. Sümegi 2013: Preliminary environmental historical results to reconstruct prehistoric human-environmental interactions in Eastern Hungary. - Central European Journal of Geosciences, 5, pp. 331-343.

Schmidt, M.W.I., J.O. Skjemstad, C. Jäger 2002: Carbon isotope geochemistry and nanomorphology of soil black carbon: black chernozemic soils in Central Europe originate from ancient biomass burning. - Global Biogeochemical Cycles, 16/4, pp. 70-1-70-8.

Stefanovits, P., Gy. Filep, Gy. Füleky 2010: Talajtan (Pedology). - Mezőgazdasági Kiadó, Budapest, 470 p. (in Hungarian)

Stoops, G. 2003: Guidelines for Analysis and Description of Soil and Regolith Thin Sections. - Soil Science Society of America, Madison, $184 \mathrm{p}$.

Sudnik-Wójcikowska, B., I.I. Moysiyenko, M. Zachwatowicz, E. Jabłońska 2011: The value and need for protection of kurgan flora in the anthropogenic landscape of steppe zone in Ukraine. - Plant Biosystems, 145, pp. 638-653.

Sümegi, P. 2012: Jelentés Hortobágy-Ecse-halom üledékföldtani vizsgálatának eredményeiről (Report on the results of the sedimentological survey of the Ecse-halom kurgan). - Manuscript, Records of Hortobágy National Park Directorate, 54 p. (in Hungarian)

Sümegi, P., B. Csökmei, G. Persaits 2005: The Evolution of Polgár Island, a Loess-Covered Lag Surface and its Influences on the Subsistence of Settling Human Cultural Groups. - In: Hum, L., S. Gulyás, P. Sümegi (Eds): Environmental Historical Studies from the Late Tertiary and Quaternary of Hungary. University of Szeged, Szeged, pp. 141-164.

Sümegi, P., G. Szilágyi, S. Gulyás, G. Jakab, A. Molnár 2013: The late quaternary paleoecology and environmental history of Hortobágy, a unique mosaicalcaline steppe from the heart of the Carpathian basin. - In: Morales Prieto, M.B., J. Traba Diaz (Eds): Steppe Ecosystems. Biological Diversity, Management and Restoration. Nova Science Publishers, New York, pp. 165-193.

Szilágyi, G., P. Sümegi, D. Molnár, Sz. Sávai 2013: Mollusc-based paleoecological investigations of the Late Copper - Early Bronze Age earth mounds (kurgans) on the Great Hungarian Plain. - Central European Journal of Geosciences, 5, pp. 465-479.

Tóth, A. 1988: Szolnok megye tiszántúli területének kunhalmai (Die Kurgane des Komitats Szolnok im Gebiet Links der Theiss). - Zounuk, 3, pp. 349-410. (in Hungarian) 